https://doi.org/10.24843/AJoAS.2021.v11.i01.p05

\title{
Pengaruh Jenis Trichoderma spp. Terhadap Pertumbuhan, Hasil, dan Keberadaan Penyakit Tanaman Kacang Tanah (Arachis hypogaea L.)
}

\author{
KOMANG INTAN CAHYANI*), I MADE SUDANA, DAN GEDE WIJANA \\ Magister Pertanian Lahan Kering, Fakultas Pertanian, Universitas Udayana \\ Jl. PB. Sudirman, Denpasar 80231 Bali \\ ${ }^{*}$ E-mail: komangintancahyani@gmail.com
}

\begin{abstract}
The Effect of Trichoderma spp. on Growth, Yield, and Presence of the Diseases in Peanut (Arachis hypogaea L.). The consumption of peanuts is increasing together with increasing population, increasing nutrition, food diversification and increasing the capacity of the food and animal feed industry. However, the supply of peanuts in Indonesia is continues decline due to low soil nutrients and leaf rust attacks. The efforts can be made to increase peanut productions by applying Trichoderma spp. in peanut seeds. The purpose of this study was to determine the effect of Trichoderma spp. on the growth and yield of peanut plants, identifying the effect of Trichoderma spp. on the resistance of peanut plants to disease and know the best type of Trichoderma spp. for peanut plants. The design used in this study was a randomized block design (RCBD) with the treatment of a single factor type Tricoderma spp. which consists of 7 levels, namely: control, T. koningii, T. viride, T.asperellum, T. harzianum, T. ressei and T. asperellum Bedugul Bali. The treatment was repeated 4 times. The experimental results showed that the treatment of Trichoderma spp. significant until very significant effect on most of the observation variables. The best Trichoderma spp. is T. asperellum which has a very significant effect on the total number of pods (24.25 pods), weight of pods contained/plant $(62.43 \mathrm{~g})$, number of seeds/plant (62.75 seeds), and lowest leaf rust intensity $(34,51 \%)$.
\end{abstract}

Keywords: Trichoderma spp. and Peanut

\section{PENDAHULUAN}

Kacang tanah (Arachis hypogaea L.) merupakan salah satu tanaman legum yang sudah dikenal dan dibudidayakan di Indonesia. Kacang tanah mempunyai nilai ekonomi tinggi, dimana dalam $100 \mathrm{~g}$ kacang tanah mengandung energi sebesar $525 \mathrm{kkal}$, protein 27,9 g, karbohidrat 17,4 g, lemak 42,7 g, kalsium 315 mg, fosfor 456 mg, dan zat besi 5,7 mg. Kebutuhan 


\section{KOMANG INTAN CAHYANI et al. Pengaruh Jenis Trichoderma spp. Terhadap...}

kacang tanah meningkat setiap tahun \pm 900.000 ton dengan produksi rata-rata setiap tahun 783.110 ton atau sekitar $87,01 \%$ (DitjenTP, 2012). Namun penyediaan kacang tanah di Indonesia selama kurun waktu 5 tahun terakhir (20122017) terus mengalami penurunan. Pada tahun 2012 produksi kacang tanah Indonesia mencapai 712.857 ton namun terus mengalami penurunan hingga menjadi 480.360 ton pada tahun 2017 (BPS, 2017).

Rendahnya produksi kacang tanah di Indonesia disebabkan karena tanaman kacang tanah di tanam di sawah dengan pengolahan tanah yang tidak bagus, akibatnya pertumbuhan akar kurang baik karena tanah bekas tanaman padi strukturnya padat, kurang oksigen, populasi mikrofloranya rendah, dan sebagian unsur hara masih terikat dalam butiran tanah dan sulit diserap oleh akar tanaman. Tanaman kacang tanah juga peka terhadap serangan penyakit karena tanaman kurang mendapat hara yang terikat untuk memproduksi metabolit sekunder yang dapat melindungi tanaman dari serangan patogen penyakit.

Salah satu upaya yang dilakukan untuk mencapai hasil tanaman kacang tanah yang optimal ialah dengan tidak menimbulkan dampak negatif terhadap kualitas tanah jangka panjang akibat dari penggunaan pupuk kimia yang berlebihan dengan menggunakan pupuk hayati Trichoderma spp. yaitu sebagai agen hayati juga merupakan pengurai bahan organik seperti karbohidrat, terutama selulosa dengan bantuan enzim selulase. Kandungan bahan organik yang terdapat didalam tanah akan dilepaskan dalam bentuk unsur hara disekitar daerah perakaran (Hardianus et al., 2017).

Sari (2017) menyatakan bahwa Trichoderma spp. mampu menekan perkembangan F.oxysporum penyebab penyakit layu stroberi secara in vitro sebesar 64\%. Trichoderma mampu menekan pertumbuhan patogen melalui proses mikoparasitisme, antibiotik, dan kompetisi dengan mekanisme antagonis yang dilakukan dengan mengeluarkan toksin berupa enzim $\beta-1,3$ glukanase, kitinase, dan selulase (Cikita et al., 2016).

Trichoderma spp. memiliki fisiologi dan morfologi yang berbeda-beda, sehingga kemampuannya dalam mengendalikan patogen juga berbeda. Oleh karena itu dilakukan penelitian penggunaan beberapa jenis jamur Trichoderma spp. untuk mendapatkan pertumbuhan dan hasil kacang tanah yang optimal.

Tujuan dari penelitian ini adalah (1) mengetahui pengaruh Trichoderma spp. 
terhadap pertumbuhan dan hasil tanaman kacang tanah, (2) menemukan pengaruh Trichoderma spp. pada ketahanan tanaman kacang tanah terhadap penyakit, (3) menemukan jenis Trichoderma spp. yang paling baik untuk tanaman kacang tanah.

\section{BAHAN DAN METODE}

Penelitian dilaksanakan di lahan PEMDA Provinsi Bali, Jl. Tantular, Renon, Denpasar. Penelitian ini dilaksanakan pada bulan April sampai Agustus 2019. Rancangan yang digunakan adalah rancangan acak kelompok (RAK) dengan perlakuan faktor tunggal jenis Tricoderma spp. yang terdiri atas 7 taraf yaitu : $\mathrm{T}_{0}=$ kontrol, $\mathrm{T}_{1}=T$. koningii, $\mathrm{T}_{2}=T$. viride, $\mathrm{T}_{3}=T$. asperellum, $\mathrm{T}_{4}=T$. harzianum, $\mathrm{T}_{5}=T$. reesei dan $\mathrm{T}_{6}=T$. asperellum Bedugul Bali. Perlakuan tersebut masing-masing diulang sebanyak 4 kali.

Pelaksanaan penelitian meliputi perbanyakan Trichoderma spp. yang dilaksanakan di laboratorium dengan steril. Sebelum diaplikasikan pada benih, biakan Trichoderma spp. terlebih dahulu diremajakan pada media Potato Dextrose Agar (PDA). Setelah tumbuh, Trichoderma spp. diperbanyak pada media cair potato dextrose broth (PDB) kemudian diinkubasi selama 7 hari pada suhu ruang hingga media tampak keruh dan penuh ditumbuhi Trichoderma spp. Tahapan selanjutnya adalah pembuatan biofertilizer Trichoderma spp. Bahan-bahan yang digunakan adalah 1 $\mathrm{kg}$ pupuk bioslury, 0,5 kg dedak, dan $10 \mathrm{~g}$ gula yang dikemas dalam kantong plastik sebagai media pembawa Trichoderma spp. Kemudian media tersebut diinokulasikan dengan $250 \mathrm{ml}$ biakan Trichoderma spp dan diinkubasi selama 7 hari. Setelah biofertilizer siap digunakan, benih kacang tanah dicampur dengan biofertilizer tersebut hingga merata yaitu tampak semua permukaan benih tertutupi oleh biofertilizer.

Variabel yang diamati adalah indeks luas daun, kandungan klorofil daun $\left(\mu \mathrm{mol} / \mathrm{m}^{2}\right)$, jumlah polong total $/ \mathrm{tan}$ (polong), jumlah polong berisi/tan (polong), berat polong berisi/ha (ton), berat biji kering oven/ha (ton), intensitas serangan penyakit karat daun (\%) dan intensitas serangan penyakit bercak daun (\%).

Data dianalisis dengan menggunakan analisis sidik ragam (anova) untuk mengetahui pengaruh perlakuan terhadap variabel pengamatan. Jika terdapat perbedaan antara perlakukan maka dilakukan uji BNT taraf 5\% untuk melihat perbedaan antara perlakuan dan melihat perlakuan yang memberikan hasil terbaik. 
KOMANG INTAN CAHYANI et al. Pengaruh Jenis Trichoderma spp. Terhadap...

\section{HASIL DAN PEMBAHASAN}

Signifikansi pengaruh perlakuan jenis Trichoderma spp. terhadap seluruh variabel yang diamati (Tabel 1.) menunjukkan bahwa perlakuan jenis
Trichoderma spp. berpengaruh nyata $(\mathrm{P}<0,05)$ sampai sangat nyata $(\mathrm{P}<0,01)$ terhadap sebagian besar variabel yang diamati kecuali pada kandungan klorofil daun yang tidak berpengaruh nyata $(\mathrm{P} \geq 0,05)$.

Tabel 1. Signifikansi pengaruh perlakuan jenis Trichoderma spp. terhadap variabel yang diamati.

\begin{tabular}{clc}
\hline No & \multicolumn{1}{c}{ Variabel } & $\begin{array}{c}\text { Perlakuan } \\
\text { Jenis }\end{array}$ \\
\hline 1 & Indeks laus daun & $*$ \\
2 & Kandungan klorofil daun $\left(\mu \mathrm{mol} / \mathrm{m}^{2}\right)$ & $\mathrm{ns}$ \\
3 & Jumlah polong total/tan (polong) & $* *$ \\
4 & Jumlah polong berisi/tan (polong) & $*$ \\
5 & Berat polong berisi/ha (ton) & $* *$ \\
6 & Hasil biji kering oven/ha (ton) & $*$ \\
7 & Penyakit karat daun $(\%)$ & $* *$ \\
8 & Penyakit bercak daun $(\%)$ & $* *$ \\
\hline 1$)$ & ns $=$ tidak berpengaruh nyata $(\mathrm{P} \geq 0,05)$ & \\
& $*=$ berpengaruh nyata $(\mathrm{P}<0,05)$ &
\end{tabular}

Hasil pengamatan menunjukkan dengan perlakuan lainnya (Tabel 2.) bahwa Trichoderma spp. dapat Semakin baik tanah dalam menyediakan air meningkatkan pertumbuhan tanaman dan hara, makin baik pula pertumbuhan seperti indeks luas daun dengan nilai tanaman. Sejalan dengan pernyataan tertinggi diperoleh pada perlakuan jenis $T$. (Pratama et al., 2015). Perkembangan asperellum $\left(\mathrm{T}_{3}\right)$ yaitu 8,32 yang berbeda nyata dengan perlakuan kontrol $\left(\mathrm{T}_{0}\right)$ dan $T$. koningii $\left(\mathrm{T}_{1}\right)$ dengan nilai berturut-turut 6,61 dan 6,91 (Tabel 2). Pada kandungan klorofil daun juga didapatkan nilai tertinggi pada jenis $T$. asperellum $\left(\mathrm{T}_{3}\right)$ yaitu 40,64 $\mu \mathrm{mol} / \mathrm{m}^{2}$ meskipun tidak berbeda nyata Trichoderma spp. pada tanah akan mampu mendekomposisi bahan organik yang ada di dalam tanah sehingga dapat memudahkan penyerapan unsur hara bagi tanaman. Aplikasi Trichoderma spp. akan menghasilkan enzim-enzim pengurai yang dapat menguraikan bahan organik, 
penguraian ini akan melepaskan hara yang terikat dalam senyawa komplek menjadi tersedia terutama unsur $\mathrm{N}$ dan $\mathrm{P}$. Nitrogen berfungsi untuk pembentukan pembentukan zat hijau daun (klorofil) serta memperbaiki pertumbuhan vegetatif tanaman seperti tinggi tanaman, jumlah daun dan indeks luas daun. Pandya \& Saraf (2010) melaporkan bahwa T. asperellum dikenal sebagai pengendali hayati terhadap beberapa patogen dan terbukti mampu meningkatkan pertumbuhan dan hasil tanaman dengan memproduksi fitohormon seperti IAA dan sitokinin.

Walaupun pemberian Trichoderma spp. tidak berpengaruh nyata terhadap kandaungan klorofil daun, tetapi dapat memberikan hasil tanaman kacang tanah yang berbeda disetiap perlakuannya. Dimana, tanaman dapat melakukan aktivitas fotosintesis dengan baik yang menyebabkan laju pertumbuhan indeks luas daun meningkat. Indeks luas daun mencerminkan besarnya intersepsi cahaya oleh tanaman. Meskipun bagian batang juga ikut mengintersepsi cahaya, tetapi aktifitas fotosintesis lebih efektif terjadi pada daun. Indeks luas daun meningkat dengan meningkatnya intensitas cahaya sampai batas optimum tanaman mengintersepsi cahaya (Duaja et al., 2012).

Tabel 2. Pengaruh jenis Trichodema spp. terhadap ILD, kandaungan klorofil daun, jumlah polong total/tan dan jumlah polong berisi/tan.

\begin{tabular}{|c|c|c|c|c|c|c|c|c|c|}
\hline \multicolumn{2}{|l|}{ Perlakuan } & \multicolumn{2}{|l|}{ ILD } & \multicolumn{2}{|c|}{$\begin{array}{l}\text { Kandungan } \\
\text { klorofil daun } \\
\left(\mu \mathrm{mol} / \mathrm{m}^{2}\right)\end{array}$} & \multicolumn{2}{|c|}{$\begin{array}{l}\text { Jumlah } \\
\text { polong } \\
\text { total/tan } \\
\text { (polong) }\end{array}$} & \multicolumn{2}{|c|}{$\begin{array}{c}\text { Jumlah } \\
\text { polong } \\
\text { berisi/tan } \\
\text { (polong) }\end{array}$} \\
\hline Kontrol & $\left(\mathrm{T}_{0}\right)$ & 6,61 & $\mathrm{c}$ & 38,45 & $\mathrm{a}$ & 18,25 & $\mathrm{c}$ & 15,25 & $\mathrm{c}$ \\
\hline T. koningii & $\left(\mathrm{T}_{1}\right)$ & 6,91 & $\mathrm{bc}$ & 38,92 & $\mathrm{a}$ & 22,75 & $\mathrm{ab}$ & 19,75 & $a b$ \\
\hline T. viride & $\left(\mathrm{T}_{2}\right)$ & 7,81 & $a b$ & 40,16 & $\mathrm{a}$ & 23,25 & $a b$ & 20,75 & $a b$ \\
\hline T. asperellum & $\left(\mathrm{T}_{3}\right)$ & 8,32 & $\mathrm{a}$ & 40,64 & $\mathrm{a}$ & 24,25 & $\mathrm{a}$ & 21,50 & \\
\hline T. harzianum & $\left(\mathrm{T}_{4}\right)$ & 7,97 & $\mathrm{a}$ & 39,52 & $\mathrm{a}$ & 20,75 & $\mathrm{bc}$ & 18,50 & $\mathrm{ab}$ \\
\hline T. reesei & $\left(\mathrm{T}_{5}\right)$ & 7,35 & $a b$ & 39,19 & $\mathrm{a}$ & 21,00 & $\mathrm{~b}$ & 18,00 & $\mathrm{bc}$ \\
\hline $\begin{array}{l}\text { T. asperellum Bedugul } \\
\text { Bali }\end{array}$ & $\left(\mathrm{T}_{6}\right)$ & 8,28 & $\mathrm{a}$ & 40,08 & $\mathrm{a}$ & 22,25 & $a b$ & 19,25 & $a b$ \\
\hline BNT 5\% & & 1,03 & & - & & 2,64 & & 3,09 & \\
\hline
\end{tabular}

2) Nilai rata-rata yang diikuti oleh huruf yang sama pada perlakuan dan kolom yang sama, berarti berbeda tidak nyata pada taraf uji BNT 5\% 
KOMANG INTAN CAHYANI et al. Pengaruh Jenis Trichoderma spp. Terhadap...

Tabel 3. Pengaruh jenis Trichodema spp. terhadap berat polong berisi/ha, berat biji kering oven/ha, intensitas penyakit karat daun dan intensitas penyakit bercak daun.

\begin{tabular}{|c|c|c|c|c|c|c|}
\hline \multicolumn{2}{|l|}{ Perlakuan } & $\begin{array}{l}\text { Berat polong } \\
\text { berisi/ha (ton) }\end{array}$ & $\begin{array}{c}\text { Berat biji } \\
\text { kering } \\
\text { oven/ha (ton) }\end{array}$ & $\begin{array}{c}\text { Intensitas } \\
\text { penyakit } \\
\text { karat daun } \\
(\%)\end{array}$ & \multicolumn{2}{|c|}{$\begin{array}{c}\text { Intensitas } \\
\text { penyakit } \\
\text { bercak daun } \\
(\%)\end{array}$} \\
\hline Kontrol & $\left(\mathrm{T}_{0}\right)$ & $2,21 \quad \mathrm{~d}$ & $0,87 \quad b$ & 56,92 a & 6,86 & a \\
\hline T. koningii & $\left(\mathrm{T}_{1}\right)$ & $3,17 \quad \mathrm{c}$ & 1,71 a & $39,20 \quad b$ & 20,36 & $\mathrm{~b}$ \\
\hline T. viride & $\left(\mathrm{T}_{2}\right)$ & $3,76 \mathrm{ab}$ & 1,81 & $36,92 \quad b$ & 21,93 & $\mathrm{~b}$ \\
\hline T. asperellum & $\left(T_{3}\right)$ & $3,90 \quad \mathrm{a}$ & 1,98 & $34,51 \quad b$ & 19,82 & $\mathrm{~b}$ \\
\hline T. harzianum & $\left(\mathrm{T}_{4}\right)$ & $3,08 \quad \mathrm{c}$ & 1,59 & $39,83 \quad b$ & 19,79 & $\mathrm{~b}$ \\
\hline T. reesei & $\left(\mathrm{T}_{5}\right)$ & 3,06 & 1,48 & $36,79 \quad b$ & 22,07 & $\mathrm{~b}$ \\
\hline $\begin{array}{l}\text { T. asperellum Bedugul } \\
\text { Bali }\end{array}$ & $\left(\mathrm{T}_{6}\right)$ & 3,29 bc & 1,52 & $38,17 \quad b$ & 21,96 & $\mathrm{~b}$ \\
\hline BNT 5\% & & 0,55 & 0,53 & 5,69 & 7,14 & \\
\hline
\end{tabular}

3) Nilai rata-rata yang diikuti oleh huruf yang sama pada perlakuan dan kolom yang sama, berarti berbeda tidak nyata pada taraf uji BNT 5\%

Tabel 2 dan 3 menunjukkan bahwa dari berbagai jenis Trichoderma spp. yang dicobakan ternyata jumlah polong total/tan, jumlah polong berisi/tan, berat polong berisi/ha dan berat biji kering oven/ha tertinggi dijumpai pada jenis T. asperellum $\left(\mathrm{T}_{3}\right)$ yang berbeda nyata dengan kontrol dengan nilai masing-masing 24,25 polong, 21,50 polong, 3,90 ton dan 1,98 ton.

Trichoderma spp. memberikan pengaruh yang sangat nyata terhadap berat polong berisi per hektar, dengan hasil tertinggi diperoleh pada T. asperellum $\left(\mathrm{T}_{3}\right)$ yaitu 3,90 ton meningkat sebesar 43,33\% bila dibandingkan dengan hasil terendah pada perlakuan kontrol $\left(\mathrm{T}_{0}\right)$ yaitu 2,21 ton.

Tanaman tumbuh dan mencapai tingkat produksi tinggi disebabkan karena unsur hara yang dibutuhkan tanaman dalam keadaan cukup dan berimbang dalam tanah. Unsur hara dan air yang diserap tanaman merupakan cerminan berat segar tanaman. Unsur hara yang diserap tanaman melalui akar bersama air akan mempengaruhi pertumbuhan seperti tinggi, jumlah daun dan luas daun. Akumulasi dari tinggi, jumlah daun dan luas daun akan mempengaruhi dari berat segar tanaman. Semakin baik pertumbuhan tanaman maka semakin meningkat pula berat segar tanaman tersebut (Haryadi et al., 2015). Menurut Rahma (2014) adanya peningkatan biomassa dikarenakan tanaman menyerap air dan hara lebih banyak,unsur hara memacu perkembangan organ pada tanaman seperti akar, sehingga tanaman 
dapat menyerap hara dan air lebih banyak selanjutnya aktifitas fotosintesis akan meningkat dan mempengaruhi peningkatan berat basah dan berat kering tanaman.

Secara umum Trichoderma spp. mempunyai kemampuan sebagai pupuk hayati dimana, Trichoderma spp. dapat menghasilkan senyawa organik yang mampu melarutkan $\mathrm{P}$ terikat pada $\mathrm{Al}$ dan $\mathrm{Fe}$ sehingga mudah diserap tanaman (Sutedjo, 1995). Trichoderma spp. juga sebagai pelarut kalium dapat memproduksi asam organik (Meena et al., 2014). Asam organik yang diproduksi oleh Trichoderma spp. seperti sitrat dan oksalat dapat merombak mineral-mineral kalium menjadi ion-ion kalium sehingga dapat dimanfaatkan oleh tanaman (Parmar \& Sindhu, 2013). Menurut Pandya \& Saraf (2010) T.asperellum juga terbukti mampu melarutkan fosfat sehingga tersedia bagi tanaman. Selain itu, T.asperellum yang diaplikasikan menunjukkan peningkatan unsur $\mathrm{Ca}, \mathrm{Mg}, \mathrm{K}$ dan $\mathrm{N}$. Unsur hara $\mathrm{P}$ dan $\mathrm{K}$ dapat merangsang pertumbuhan akar, meningkatkan pembungaan, memperkuat daun, bunga dan buah, membantu pembentukan protein dan karbohidrat sehingga dapat memproduksi biji lebih banyak, pemasakan biji dan polong sehingga dapat meningkatkan berat polong berisi.

Jenis Trichoderma spp. juga memberikan pengaruh sangat nyata terhadap intensitas serangan penyakit. Pada perlakuan Trichoderma spp., persentase serangan penyakit karat daun lebih rendah dibandingkan dengan tanaman kontrol. Tanaman yang diberikan Trichoderma spp. intensitas serangan penyakitnya berkisar antara 34,51\%-39,83\%, sedangkan pada tanaman kontrol intensitas serangan penyakitnya 56,92\% (Tabel 3). Ditinjau dari jenis, ternyata tanaman yang paling rendah terserang penyakit adalah tanaman yang diberikan perlakuan jenis $T$. asperellum yaitu hanya $34,51 \%$ yang menurun sebesar 39,37\% jika dibandingkan dengan kontrol (Gambar 1). Berbanding terbalik pada penyakit bercak daun serangan penyakitnya lebih tinggi dibandingkan dengan kontrol. Penyakit karat daun dan bercak daun menyebabkan menurunnya area fotosintesis sehingga dapat menurunkan hasil tanaman berkisar 10\%-50\% (Damicone \& Melouk, 2013). 
KOMANG INTAN CAHYANI et al. Pengaruh Jenis Trichoderma spp. Terhadap...

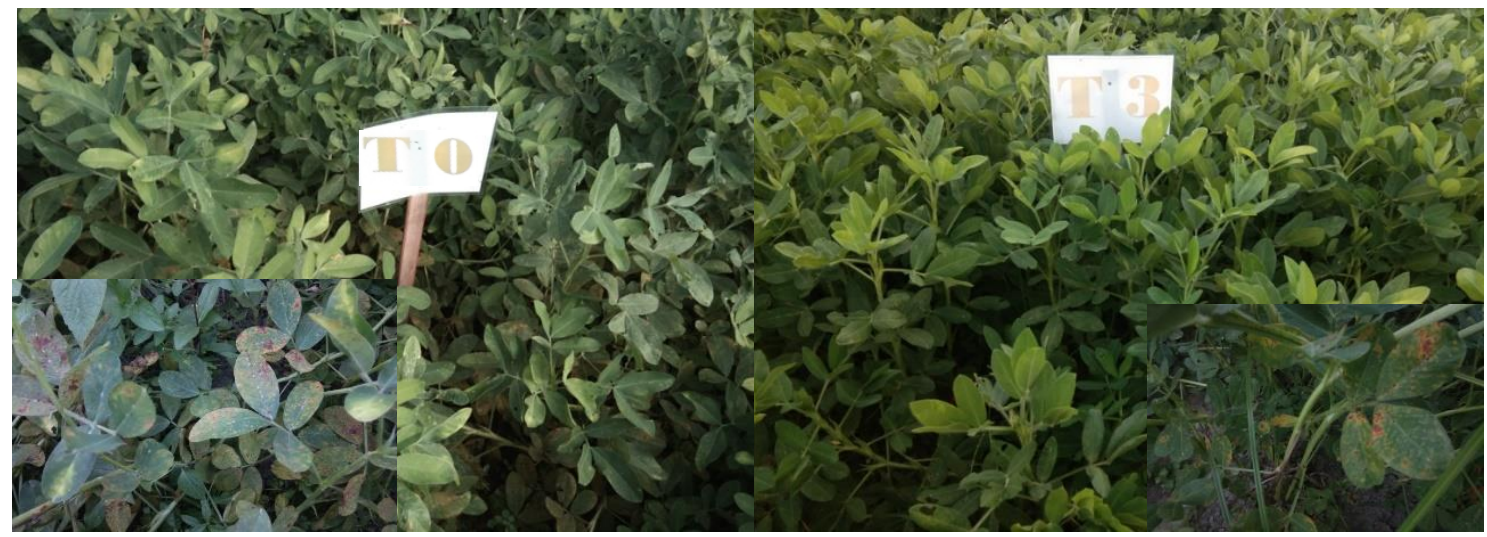

Gambar 1. Serangan Penyakit Karat Daun Pada Kontrol $\left(\mathrm{T}_{0}\right)$ dan T. asperellum $\left(\mathrm{T}_{3}\right)$

Selain mampu menghasilkan fitohormon dan menyediakan hara bagi tanaman, Trichoderma spp. dalam peranannya sebagai agensia hayati juga bekerja berdasarkan mekanisme antagonis yang berperan dalam pengendalian penyakit (Wahyuno et al., 2003). Mekanisme yang dilakukan oleh Trichoderma spp. terhadap patogen adalah mikoparasit, antibiosis dan kompetisi (Arwiyanto, 1997). Dalam mengendalikan penyakit karat daun, mekanisme antagonis yang digunakan oleh T. asperellum adalah antibiosis. Pada awalnya, Trichoderma spp. mengkolonisasi ataupun menembus jaringan akar tanaman. Kemampuan Trichoderma spp. dalam mengkolonisasi akar menyebabkan jamur petogen tidak memiliki ruang untuk menempel perakaran tanaman dan menginfeksi sampai menyebabkan timbulnya penyakit. Ketika Trichoderma spp. menempel perakaran tanaman maka perakaran tanaman akan sehat, pertumbuhan tanaman meningkat sehingga tanaman mampu memproduksi antibiotik dan metabolit sekunder seperti asam sitrat, etanol dan berbagai enzim seperti urease, selulase, glukanase dan kitinase. Enzim ini berguna untuk meningkatkan efisiensi aktivitas biokontrol terhadap patogen. $T$. asperellum mampu memproduksi metabolit sekunder yang bersifat antifungi seperti viridol, azaphilon, peptaibol dan peptaibiotik. Karakteristik yang sangat dikenal pada T.asperellum yaitu mampu memproduksi enzim kitinolitik (Viterbo et al., 2010), selain dihasilkannya $\beta 1,3-$ glukanase, $\beta$ 1,6-glukanase, selulase dan protease, juga mampu menginduksi ketahanan sistemik terhadap patogen daun (Yedidia et al., 1999). 


\section{SIMPULAN}

Berdasarkan hasil penelitian dan pembahasan di atas dapat disimpulkan yaitu Pemberian Trichoderma spp. berpengaruh nyata sampai sangat nyata terhadap pertumbuhan dan hasil tanaman, seperti indeks luas daun, jumlah polong total/tan, jumlah polong berisi/tan, berat polong berisi/ha, berat biji kering oven/ha. Trichoderma spp. mempengaruhi keberadaan penyakit karat daun dan bercak daun. T. asperellum memiliki kemampuan terbaik dalam menekan penyakit karat daun menjadi 34,51\%. T. asperellum mampu meningkatkan pertumbuhan dan hasil tanaman, serta mampu menekan serangan penyakit pada tanaman kacang tanah.

\section{DAFTAR PUSTAKA}

Arwiyanto, T. (1997). Pengendalian Hayati Penyakit Layu Bakteri Tembakau: 1. Isolasi Bakteri Antagonis. Jurnal Perlindungan Tanaman Indonesia, 3(1), 54-60.

BPS. (2017). Prakiraan Produksi Palawija Hasil Rakor Pembahasan antara Kementan dan BPS Tahun 20122017.

Cikita, D., Khotimah, S., \& Linda, R. (2016). Uji antagonis Trichoderma spp . terhadap Phytophthora palmivora Butl . penyebab penyakit busuk buah Kakao ( Theobroma cacao L .). Protobiont, 5(3), 59-65. http://jurnal.untan.ac.id/index.php/jpr b/article/download/17016/14560

Damicone, J., \& Melouk, H. (2013).
Soilborne Diseases of Peanut. Oklahoma Cooperative Extension Service, 7. http://osufacts.okstate.edu DitjenTP, D. J. T. P. (2012). Road Map Peningkatan Produksi Kacang Tanah dan Kacang Hijau Tahun 2010-2014. Direktorat Jenderal Tanaman Pangan.

Duaja, M., Arzita, \& Redo, Y. (2012). Analisis Tumbuh Selada (Lactuca Sativa L) Pada Perbedaan Jenis Pupuk Organik Cair. Jurnal Universitas Jambi, 1(1), 33-41.

Hardianus, Suryantini, R., \& Wulandari, R. S. (2017). Efektivitas trichoderma dan pupuk kandang terhadap pertumbuhan tinggi dan diameter semai acacia mangium pada tanah ultisol. Jurnal Hutan Lestari, 5(2), 521-529.

Haryadi, D., Yetti, H., \& Yoseva, S. (2015). Pengaruh Pemberian Beberapa Jenis Pupuk Terhadap Pertumbuhan Dan Produksi Tanaman Kailan (Brassica alboglabra L.). JOM Faperta, 2(2), 110.

Meena, V., Maurya, B., \& Bahadur, I. (2014). Potassium solubilization by bacterial strain in waste mica. Bangladesh Journal of Botany, 43(2), 235-237.

https://doi.org/10.3329/bjb.v43i2.216 80

Pandya, U., \& Saraf, M. (2010). Role of Single Fungal Isolates and Consortia as Plant Growth Promoters under Saline Conditions. Research Journal of Biotechnology, 5(3), 5-9.

Parmar, P., \& Sindhu, S. S. (2013). Potassium Solubilization by Rhizosphere Bacteria: Influence of Nutritional and Environmental Conditions. Journal of Microbiology Research, 3(1), 25-31.

Pratama, R. E., Mardhiansyah, M., \& Oktorini, Y. (2015). Waktu Potensial Aplikasi Mikoriza dan Trichoderma 
KOMANG INTAN CAHYANI et al. Pengaruh Jenis Trichoderma spp. Terhadap...

Spp. Untuk Meningkatkan

Pertumbuhan Semai Acacia mangium. JOM Faperta, 2(1).

Rahma, A. (2014). Pengaruh Pupuk Organik Cair Berbahan Dasar

Limbah Sawi Putih (Brassica Chinensis L.) Terhadap Pertumbuhan Tanaman Jagung Manis (Zea Mays L. Var. Saccharata).

Sari, I. G. A. D. V. (2017). Identifikasi Penyebab Penyakit Layu pada Tanaman Stroberi (Fragaria sp.) di Desa Pancasari dan Potensi Pengendaliannya dengan Mikroba Antagonis. Universitas Udayana.

Sutedjo, M. M. (1995). Pupuk dan cara pemupukan (5th ed.). Rineka Cipta.

Viterbo, A., Landau, U., Kim, S., Chernin, L., \& Chet, I. (2010). Characterization of ACC deaminase from the biocontrol and plant growthpromoting agent Trichoderma asperellum T203. FEMS Microbiology Letters, 305(1), 42-48. https://doi.org/10.1111/j.15746968.2010.01910.x

Wahyuno, D., Manohara, D., \& Mulya, K. (2003). Peranan bahan organik pada pertumbuhan dan daya antagonisme Trichoderma harzianum dan pengaruhnya terhadap P. capsici. pada tanaman lada. Jurnal Fitopatologi Indonesia, 7, 76-82.

Yedidia, I., Benhamou, N., \& Chet, I. (1999). Induction of Defense Responses in Cucumber Plants (Cucumis sativus L.) by the Biocontrol AgentTrichoderma harzianum. Applied and Environmental Microbiology, 65(3), 1061-1070.

https://doi.org/10.1128/AEM.65.3.10 61-1070.1999 